\title{
The Effectiveness of Ongoing Assessment on Physics Learning in Improving Students Critical Thinking Skills
}

\author{
Agus Setiawan ${ }^{1}$, Undang Rosidin ${ }^{1} \&$ Abdurrahman $^{1}$ \\ ${ }^{1}$ Physics Education Postgraduate Department, University of Lampung, Indonesia \\ Correspondence: Abdurrahman, University of Lampung, Indonesia. E-mail: abdurrahman.1968@fkip.unila.ac.id
}

Received: April 16, 2019; Accepted: April 25, 2019; Published: May 21, 2019

\begin{abstract}
This research was conducted to determine the effectiveness of the ongoing assessment of student learning outcomes. There were three groups of students in this study who used different types of questions. The type of questions used are multiple choices, essays, and true/false. Effectiveness is obtained from the average $\mathrm{N}$-gain score. The results of the product effectiveness test show different results for each type of question. The effectiveness of the ongoing assessment with the type of multiple choice questions and true/false based on the results of the average $\mathrm{n}$-gain included in the category is quite effective. The effectiveness of the ongoing assessment with the type of essay question based on the average n-gain results is included in the less effective category.
\end{abstract}

Keywords: ongoing assessment, physics learning, critical thinking skills

\section{Introduction}

In the 21 st century, where rapid development of science and technology takes place, everyone will be required to become an individual who is able to compete globally. In such competition, one must certainly have the ability to make it a superior human resource. One of the competencies which characterize superior human resources is highorder thinking skills. High-order thinking includes critical thinking skills and the ability to think creatively. Students' critical thinking skills can be improved through assessment of spiritual thinking (Barnett \& Francis, 2012). Some questions that can be used to improve students' critical thinking skills are multiple choice, short answers, true-false, matching, sorting and essays (Pradana \& Suyatna, 2017).

The implementation of assessment emphasizes questions that require deep thinking to be able to measure high-order thinking skills and measure not only the results of students' work, but also the processes of students' work (Kearney, 2013). Critical thinking ability refers to the ability of students to analyze information, determine relevant information and interpret information in solving problems (Wylie \& Neely, 2016; Loes et al., 2015).

Students will not be able to develop their critical thinking skills properly if they are not challenged to use them in learning (Dellos, 2015). Ongoing assessment is an assessment that not only assesses results but also assesses student processes in solving problems during learning (Leirhaug \& MacPhail, 2015). Ongoing assessment will provide meaningful experiences that enhance students' critical thinking skills (Abosalem, 2016).

Ongoing assessment is a combination of student thinking processes and teacher feedback needed to improve student understanding of a particular topic or concept. Feedback is one of the factors that has a strong impact on the success of the learning process and student achievement (Heitink et al., 2016).Giving feedback both reflectively and constructively will improve the quality of student learning (Thomas et al., 2011). Abdurrahman et al. (2018) emphasize that active and dynamic learning is very dependent on feedback.

Observations conducted on 26 students showed more than 53\% of students had low conceptual abilities. Low conceptual understanding causes students to experience difficulties in solving problems or having difficulty learning. A student with a low conceptual understanding will experience difficulties in following active learning, requiring critical thinking skills (Kiryak \& Çalik, 2018). The best way to stimulate a student's conceptual understanding is to ask questions that interfere with their thinking (Chin, 2006). In addition, the role of the teacher as a facilitator is also very important. Teachers who provide assistance optimally will produce a higher understanding of students' concepts (Geveke et al., 2016). 
The purpose of this study was to describe the effectiveness of ongoing assessments to improve students' critical thinking skills. based on these obejectives, the formulation of problems in this research as: how effective the ongoing assessment of physics learning in improving students' critical thinking skills?

\section{Method}

The research design used pretest-posttest group design (Creswell, 2012). This test was applied to class X with three classes, namely class A which used multiple choice type ongoing assessment, class B which used true or false type ongoing assessment, and class $C$ which used essay answer type ongoing assessment. The learning in each class were carried out through three stages. Firstly, the students were given a pre-test to discover the knowledge concerning on the material before learning. Secondly, the learning process used ongoing assessment. Students were given questions according to the material and were asked to answer with evidence or data. Then the teacher gave feedback in the form of evaluation or clarification. This process was carried out on a cyclic basis until the material competence was complete. Thirdly, post-test was given to test students' critical abilities and conceptual knowledge after learning. Table 1 shows the form of research design used.

Table 1. Pretest-Posttest Group Design

\begin{tabular}{cccc}
\hline Class & Pre-test & Treatment & Post-test \\
\hline $\mathrm{A}$ & $\mathrm{O}$ & $\mathrm{X}_{1}$ & $\mathrm{O}$ \\
$\mathrm{B}$ & $\mathrm{O}$ & $\mathrm{X}_{2}$ & $\mathrm{O}$ \\
$\mathrm{C}$ & $\mathrm{O}$ & $\mathrm{X}_{3}$ & $\mathrm{O}$ \\
\hline
\end{tabular}

Pre-test was carried out before the learning begins, while post-test was conducted when the subject is studied. The test consists of 9 questions with three types namely multiple choices, true/false, and essays. Students must provide a reason or solution to answer each question. Tests were carried out to measure the improvement of students' critical thinking skills by usingassessment rubrics as shown in Table 2.

Table2. Critical Thinking Skills Assessment Score

\begin{tabular}{ll}
\hline Score & Rubric \\
\hline 5 & $\begin{array}{l}\text { The answers given are correct, complete, clear, focused, and accurate. Points related to the questions } \\
\text { are clearly stated to support the answers given. }\end{array}$ \\
3 & $\begin{array}{l}\text { The answers given are clear and sufficiently focused, but incomplete. The connection between the } \\
\text { answers and the questions is less accurate. }\end{array}$ \\
1 & $\begin{array}{l}\text { The answers given are not in accordance with what is meant in the question, it contains inaccurate } \\
\text { information, or it indicates a lack of mastery of the material. }\end{array}$ \\
0 & No answer
\end{tabular}

(Stiggins, 1994)

The effectiveness of learning activities from the three types of ongoing assessment tests are seen based on the NGain value. The N-gain value shows how much the student's ability increases after learning. The N-Gain data is converted according to Table 3 .

Table 3. The mean score of N-Gainand Category

(Hake, 1998)

\begin{tabular}{ll}
\hline Mean N-Gain & Category \\
\hline$(\mathrm{g})>0,70$ & High \\
$0,30<(\mathrm{g})>0,70$ & Medium \\
$0,30>(\mathrm{g})$ & Low \\
\hline
\end{tabular}

\section{Results}

The product developed in this researchis ongoing assessment on Work and Energy. Ongoing assessment aims to improve students' critical thinking skills and students' conceptual knowledge. 
Ongoing assessment is developed in three types of questions, namely, multiple choice, true-false, and essay type. The questions in the ongoing assessment were prepared based on indicators adjusted to basic competencies according to the curriculum used in schools and indicators of critical thinking in Bloom's taxonomy. The questions developed are mapped with each indicator proportionally. Table 4 presents a mapping between questions and indicators.

Table 4. The Mapping of Questions and Indicators

\begin{tabular}{|c|c|c|}
\hline $\begin{array}{ll}\text { Indicators } & \text { of } \\
\text { Achievement } & \\
\end{array}$ & $\begin{array}{l}\text { Questions in } \\
\text { ordered number }\end{array}$ & The Stages of Giving Questions \\
\hline \multirow{3}{*}{ Concluding the concept of work } & ( & $\begin{array}{l}\text { After the students learn the definition of work } \\
\text { and its examples. }\end{array}$ \\
\hline & 2 & \multirow{2}{*}{$\begin{array}{l}\text { After the students learn the equation and graphic } \\
\text { of work. }\end{array}$} \\
\hline & 3 & \\
\hline \multirow{2}{*}{ Analyzing work on moving object } & 4 & \multirow{2}{*}{$\begin{array}{l}\text { After the students discuss about the work of an } \\
\text { object which has velocity and acceleration }\end{array}$} \\
\hline & 5 & \\
\hline Comparing work on different track. & 6 & $\begin{array}{l}\text { When the students are discussing about work on } \\
\text { different track }\end{array}$ \\
\hline \multirow{3}{*}{$\begin{array}{l}\text { Analyzing the concept of potential } \\
\text { energy }\end{array}$} & 1 & \multirow{3}{*}{$\begin{array}{l}\text { After the students learn the definition } \\
\text { ofpotential energy and its equation }\end{array}$} \\
\hline & 8 & \\
\hline & 9 & \\
\hline \multirow{3}{*}{$\begin{array}{l}\text { sAnalyzing the concept of kinetic } \\
\text { energy }\end{array}$} & 10 & $\begin{array}{l}\text { When the students are discussing about factors } \\
\text { that influence kinetic energy }\end{array}$ \\
\hline & 11 & \multirow{2}{*}{$\begin{array}{l}\text { After the students learn the factors that influence } \\
\text { kinetic energy and its equation }\end{array}$} \\
\hline & 12 & \\
\hline \multirow{2}{*}{$\begin{array}{l}\text { Analyzing the concept of mechanical } \\
\text { energy }\end{array}$} & 13 & \multirow{4}{*}{$\begin{array}{l}\text { After the students learn the equation of } \\
\text { mechanical energy } \\
\text { After the students discuss about the relationship } \\
\text { of work and potential energy }\end{array}$} \\
\hline & 14 & \\
\hline \multirow{2}{*}{$\begin{array}{l}\text { Analyzing the relationship of work } \\
\text { and potential energy }\end{array}$} & 15 & \\
\hline & 16 & \\
\hline \multirow{2}{*}{$\begin{array}{l}\text { Analyzing the relationship of work } \\
\text { and kinetic energy }\end{array}$} & 17 & \multirow{2}{*}{$\begin{array}{l}\text { After the students learn the relationship of work } \\
\text { and kinetic energy }\end{array}$} \\
\hline & 18 & \\
\hline \multirow{2}{*}{$\begin{array}{l}\text { Proving the relationship of work and } \\
\text { potential energy and kinetic energy }\end{array}$} & 19 & \multirow{3}{*}{$\begin{array}{l}\text { After the students learn the equation of the } \\
\text { relationship of work and kinetic energy }\end{array}$} \\
\hline & 20 & \\
\hline $\begin{array}{l}\text { Formulating the equation of the } \\
\text { relationship ofwork and potential } \\
\text { energy and kinetic energy }\end{array}$ & 21 & \\
\hline Proving the problem solving of & 22 & \multirow{5}{*}{$\begin{array}{l}\text { After the students learn the law of mechanical } \\
\text { energy conservation and its equation. }\end{array}$} \\
\hline $\begin{array}{l}\text { movement by using lawof } \\
\text { Conservation of Mechanical Energy }\end{array}$ & 23 & \\
\hline \multirow{3}{*}{$\begin{array}{l}\text { Designing the problem solving of } \\
\text { movement by using lawof } \\
\text { Conservation of Mechanical Energy }\end{array}$} & 24 & \\
\hline & 25 & \\
\hline & 26 & \\
\hline
\end{tabular}

The learning were conducted in three classes, namely MIA 1 which used the true-false type ongoing assessment, MIA 3 which used multiple choice type ongoing assessment,MIA 4 which used essay typeongoing assessment. The trial was conducted in three stages, namely pre-test, learning with ongoing assessment, and post-test. The pretest was given to discover students' initial knowledge concerning on the material before learning. The results of the mean of pre-test of the three classes are presented in Figure 1. 


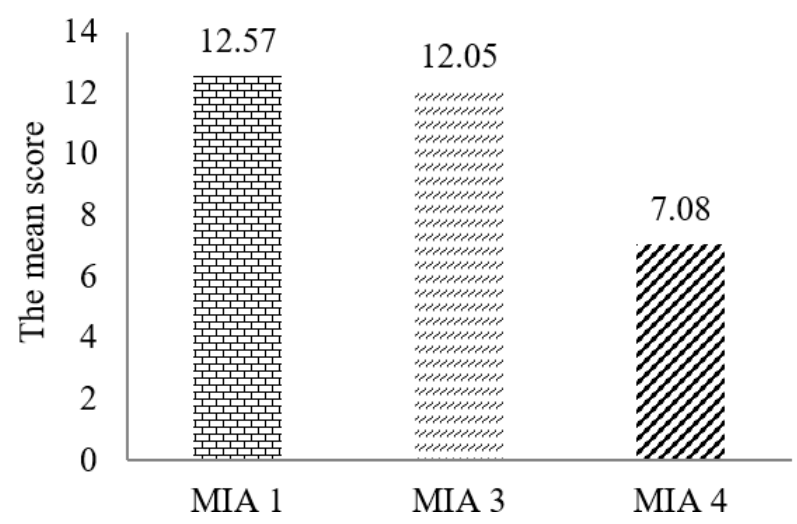

Figure 1. The Mean of Pre-test Score in Each Class

Based on Figure 1, it is known that pre-test scores means from three classes is different. The difference in the pretest scores means that students' initial abilities in each class are different.

While the results of the post-test can be seen in Figure 2. The distribution of post-tests aims to test students' critical abilities and conceptual knowledge after learning. Figure 2. shows that the mean of post-test from the three classes is different.

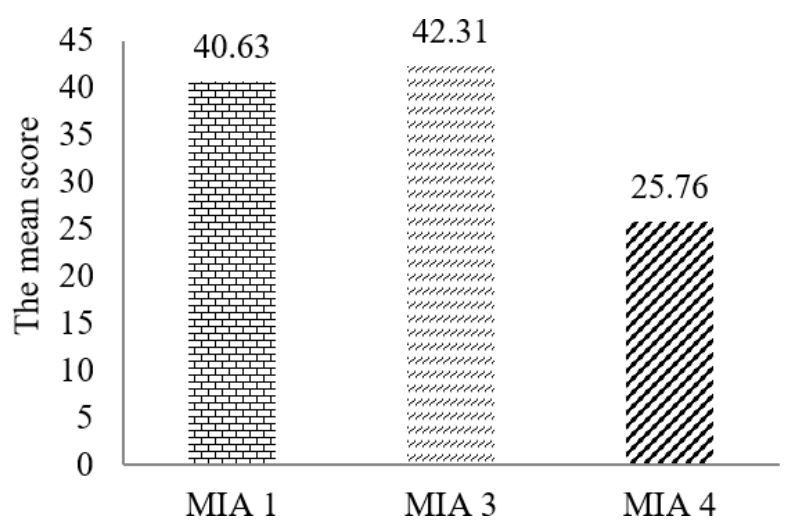

Figure 2. The Mean of Post-test Score in Each Class

Based on Figure 3, the mean of n-gain of each class is shown. After being converted according to the Table 3, the mean of n-gain of MIA 1 and MIA 3 is in the medium category, so it can be concluded that learning using ongoing assessment in both classes is quite effective. While, the meanof n-gain of MIA 4 is in the low category. It shows that the learning using ongoing assessment at MIA 4 is less effective. These results are also in accordance with statistical analysis using One Way Anova which are shown in Table 6.

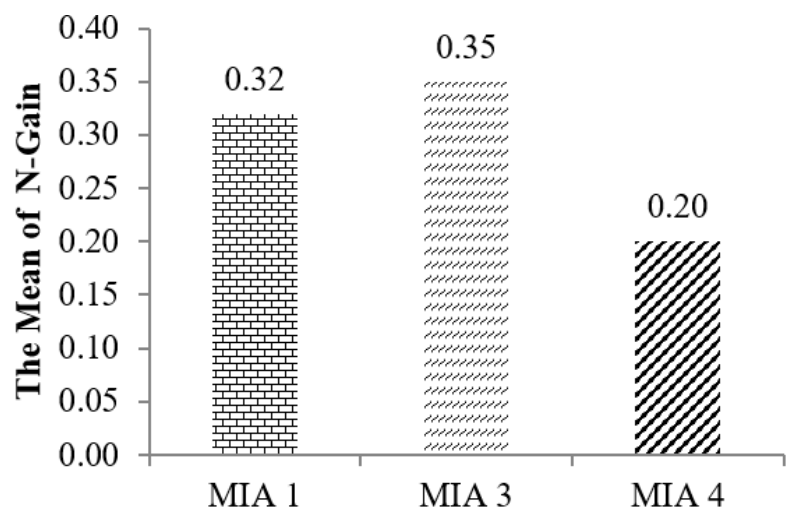

Figure 3. The Mean of N-Gain in Each Class 
Based on the data in Table 5, it is known that the significance value is less than 0.05 . This shows that there are differences in n-gain from the three classes. Based on the results of the post ANOVA test, Tukey HSD test, in Table 6 shows that MIA 4 has a n-gain difference with MIA 1 and MIA 3.

Table 5. The Results of One Way Anova from N-Gain

\begin{tabular}{llllll}
\hline & Sum of Squares & $\mathrm{df}$ & Mean Square & F & Sig. \\
\hline Between Groups & .316 & 2 & .158 & 28.937 & .000 \\
Within Groups & .448 & 82 & .005 & & \\
Total & .763 & 84 & & & \\
\hline
\end{tabular}

Table 6. The Results of Tukey HSD test from N-Gain

\begin{tabular}{|c|c|c|c|c|c|c|}
\hline \multirow[t]{2}{*}{ (I) kelas } & \multirow[t]{2}{*}{ (J) kelas } & \multicolumn{2}{|c|}{ Mean DifferenceStd. Error } & \multirow[t]{2}{*}{ Sig. } & \multicolumn{2}{|c|}{$95 \%$ Confidence Interval } \\
\hline & & $(\mathrm{I}-\mathrm{J})$ & & & Lower Bound & Upper Bound \\
\hline \multirow{2}{*}{ mial } & mia3 & -.02397 & .01951 & .440 & -.0705 & .0226 \\
\hline & mia4 & $.11848^{*}$ & .01931 & .000 & .0724 & 1646 \\
\hline \multirow{2}{*}{ mia3 } & mial & .02397 & .01951 & .440 & -.0226 & 0705 \\
\hline & mia4 & $.14245^{*}$ & .02030 & .000 & .0940 & 1909 \\
\hline \multirow{2}{*}{ mia4 } & mial & $-.11848^{*}$ & .01931 & .000 & -.1646 & -.0724 \\
\hline & mia3 & $-.14245^{*}$ & .02030 & .000 & -.1909 & -.0940 \\
\hline
\end{tabular}

\section{Discussion}

Ongoing assessment helps the teachers and students in detecting the location of students' mistakes and helps the teacher to provide feedback to students' answers. Teachers' feedback can be in the form of support towards students who answer the questions correctly and in the form of directions for students whose answers are still wrong. The directions are given in the form of information needed by students according to students' errors in answering. The feedback in learning which uses ongoing assessment is very important because feedback will make the learning more active (Abdurrahman et al., 2018; Salihu et al., 2017). The existence of feedback also shows that the teachers act as facilitators for the students in understanding concepts and improving their critical thinking skills (Salihu et al., 2017). This is in accordance with the results of the observation of the aspects of the reaction principle included in the very high category.

The learning which uses ongoing assessment receives responses from the students in those three classes with high category. Students' responses consist of several aspects, namely, student perceptions of learning activities, student interest in learning, students' perceptions of ongoing assessment in improving critical thinking skills, and student responses to teacher attitudes in learning.

The learning which uses ongoing assessment gives freedom to students in asking questions or expressing opinions to both the teacher and their friends. This giving of freedom will ease the students in understanding the materials. In addition, this will improve critical thinking skills and conceptual abilities because students will know that a problem can be solved using different ways (Romli et al., 2018).

The use of ongoing assessment will make the students focus on understanding one sub-material. This is because in the learning which uses ongoing assessment, questions are given directly after the students learn about these sub-material. If the students answer incorrectly, they can immediately find out the location of the mistake and correct it according to the feedback from the teacher. Feedback motivates students to solve problems (Espasa \& Meneses, 2010; Krause et al., 2009), increases students' ability to assess themselves (Pokorny \& Pickfort, 2010), and guides students in finding several solutions (Abdurrahman et al., 2018; Karakiozis \& Papakitsos, 2018).

This kind of learning activities which are sustainable at each competency indicator learning will foster students' experience. Critical thinking can be enhanced by continuous training that provides meaningful experiences, including scaffolding process in learning activities (Nurulsari et al., 2017).

Based on the results of the n-gain statistical analysis in Table 5 regarding the improvement of critical thinking skills and conceptual knowledge of students from three classes, the significance value is less than 0.05 . This means that critical thinking skills of students from three classes have different improvements. In Figure 3 , the mean of ngain values for each class are presented, where the MIA 3 class has the highest mean of n-gain value and the MIA 
4 class has the lowest mean of $n$-gain value. One of the differences in the ability improvement is influenced by the initial abilities of different students. Table 6 shows that the class MIA 4 has differences from the others. This is due to different initial abilities (Figure 1). Initial ability is very important to drive constructive activities for students (Van Blankenstein et al., 2013). Low initial ability will make students more difficult to develop (Schunk, 2005). Therefore the initial ability Mia 4 the lowest grade, the increase in critical thinking skills will be slower than any other class.

\section{References}

Abdurrahman, A., Saregar, A., \& Umam, R. (2018). The Effect Of Feedback As Soft Scaffolding On Ongoing Assessment Toward The Quantum Physics Concept Mastery Of The Prospective Physics Teachers. Jurnal Pendidikan IPA Indonesia, 7(1), 16-22.

Abosalem, Y. (2016). Assessment Techniques and Students' Higher-Order Thinking Skills. International Journal of Secondary Education, 4(1), 1-11.

Barnett, J. E., \& Francis, A. L. (2012). Using higher order thinking questions to foster critical thinking: A classroom study. Educational Psychology, 32(2), 201-211.

Chin, C. (2006). Classroom interaction in science: teacher questioning and feedback to students' responses. Internationa Journal of Science Education, 28(11), 1315-1346.

Creswell, J. W. (2012). Educational Research: Planning, Conducting, and Evaluating quantitative and qualitative research. Boston: Pearson Education.

Dellos, R. (2015). Kahoot! A digital game resource for learning. International Journal of Instructional Technology and Distance Learning, 12(4), 49-52.

Espasa, A., \& Meneses, J. (2010). Analysing feedback processes in an online teaching and learning environment: an exploratory study. HigherEducation, 59(3), 277-292.

Geveke, C., Steenbeek, H., Doornenbal, J., \& van Geert, P. (2016). Improving Pupils' Conceptual Understanding by a Connected In-school and Out-of-school Science Program: A Multiple Case Study. American Journal of Educational Research, 4(1), 115-125.

Hake, R. R. (1998). Interactive-engagement versus traditional methods: A six-thousand-student survey of mechanics test data for introductory physics courses. American Journal of Physics. 66 (1): 64-74.

Heitink, M. C., Van der Kleij, F. M., Veldkamp, B. P., Schildkamp, K., \& Kippers, W. B. (2016). A systematic review of prerequisites for implementing assessment for learning in classroom practice. Educational Research Review, 17, 50-62.

Karakiozis, K., \& Papakitsos, E. C. (2018). Attitudes of Teachers Who Implement School Mediation Programmes:A Case Study. International Educational Research, 1(2), 16-25.

Kearney, S. (2013). Improving engagement: the use of 'Authentic self-and peer-assessment for learning' to enhance the student learning experience. Assessment \& Evaluation in Higher Education, 38(7), 875-891.

Kiryak, Z., \& Çalik, M. (2018). Improving grade 7 students' conceptual understanding of water pollution via common knowledge construction model. International Journal of Science and Mathematics Education, 16(6), 1025-1046.

Krause, U. M., Stark, R., \& Mandl, H. (2009). The effects of cooperative learning and feedback on e-learning in statistics. Learning and instruction, 19(2), 158-170.

Leirhaug, P. E., \& MacPhail, A. (2015). 'It's the other assessment that is the key': three Norwegian physical education teachers' engagement (or not) with assessment for learning. Sport, Education and Society, 20(5), 624-640.

Loes, C. N., Salisbury, M. H., \& Pascarella, E. T. (2015). Student perceptions of effective instruction and the development of critical thinking: A replication and extension. Higher Education, 69(5), 823-838.

Nurulsari, N., Abdurrahman, A., \& Suyatna, A. (2017). Development of soft scaffolding strategy to improve student's creative thinking ability in physics. Journal of Physics: Conference Series, 909(1), 1-8.

Pokorny, H., \& Pickford, P. (2010). Complexity, cues, and relationships: Student perceptions of feedback. Active Learning in Higher Education, 11(1), 21-30.

Pradana, F. A., \& Suyatna, A. (2017). The Needs of Interactive Electronic School Books to Enhance the Critical Thinking Skills of the Students. Advances in Social Science, Education and Humanities Research (ASSEHR), 
(158),263-271.

Romli, S., Abdurrahman, A., \& Riyadi, B. (2018). Designing students' worksheet based on open-ended approach to foster students' creative thinking skills. Journal of Physics: Conference Series, 948-1.

Salihu, L., Aro, M., \& Räsänen, P. (2017). Dynamic potential of feedback in self-regulated learning and motivation of children with mathematical learning difficulties. Hrvatska revija za rehabilitacijska istraživanja, 53(2), 111-129.

Schunk, D. H. (2005). Self-Regulated Learning: The Educational Legacy of Paul R Pintrich. Educational Psycologist, 40(2), 85-94.

Stiggnis, R. J. (1994). Student-Centered Classroom Assessment. New York. Macmillan College Publishing Company.

Thomas, G., Martin, D., \& Pleasants, K. (2011). Using self and peer-assessment to enhance students' future learning in higher education. Journal of University Teaching \& Learning Practice, 8(1), 5.

Van Blankenstein, F. M., Dolmans, D. H., Van der Vleuten, C. P., \& Schmidt, H. G. (2013). Relevant prior knowledge moderates the effect of elaboration during small group discussion on academic achievement. Instructional Science, 41(4), 729-744.

Wylie, C., \& Neeley, K. (2016). Learning Out Loud (LOL): How Comics Can Develop the Communication and Critical Thinking Abilities of Engineering Students. In Proceedings of the 2016 ASEE Annual Conference.

\section{Copyrights}

Copyright for this article is retained by the author(s), with first publication rights granted to the journal.

This is an open-access article distributed under the terms and conditions of the Creative Commons Attribution license (http://creativecommons.org/licenses/by/4.0/). 